\title{
Alternative Forms of Tourism in Mountain Tourism Destination: A Case Study of Bjelašnica (Bosnia and Herzegovina)
}

\author{
Vuk Tvrtko Opačić ${ }^{A}$, Amra BandaB* \\ Received: May 13, 2017 | Revised: December 08, 2017 | Accepted: December 27, 2017 \\ DOI: $10.5937 / 22-16621$
}

\begin{abstract}
For better development of alternative tourism supply in mountain tourism destinations it is necessary to identify and evaluate tourism attractions that could be better valorised when creating tourism products. It is an essential part of the destination analysis to determine perception of local population and tourists when evaluating tourism attractiveness. Olympic Mountain Bjelašnica in Bosnia and Herzegovina is a representative case study of mountain tourism destination, whose recent phase of tourism development is characterized by a variety of tourism supply that allows practicing many forms of tourism with the dominance of the winter tourist season and the skiing tourism of mass character. The principal aim of the study is to determine the differences in the evaluation of tourism attractions of alternative tourism in tourism supply of Bjelašnica within and between group of local residents and tourists. Direct survey was conducted during the summer 2016 and sample included 98 local residents and 111 tourists. Results show: a) tourists evaluate most of attractions higher then local residents, b) some attractions are higher evaluated by younger and more educated local residents, c) older tourists evaluate cultural and historical heritage better, while tourists with college degree are most satisfied with tourism and recreational infrastructure considering the age, gender and level of education, and d) all clusters of attractions are rated as more attractive by tourists who stay at purpose-built mountain tourist resort Babin Do, compared to those in Bjelašnica's villages. Results can be applied as a guideline to raise local residents' awareness of tourism attractions and developing more specific tourism supply that will address not solely mass tourism, but also alternative forms of tourism.
\end{abstract}

Keywords: tourism attractions, tourism supply, mountain tourism, alternative forms of tourism, Bjelašnica, Bosnia and Herzegovina

\section{Introduction}

Mountain tourism with numerous types of activities represents one of the most significant forms of tourism (Heberlein et al., 2002; Yang et al., 2009; Voiculescu et al., 2012). Bosnia and Herzegovina is endowed with hilly - mountainous relief that always had a place in its tourism supply. Together with Igman, Jahorina, Vlašić, Kupres and Blidinje, Bjelašnica is one of the leading ski resorts and the highest ski centre in Bos-

A Department of Geography, Faculty of Science, University of Zagreb, Marulićev trg 19/II, 10000 Zagreb, Croatia; vtopacic@geog. pmf.hr

B Department of Geography, Faculty of Science, University of Sarajevo, Zmaja od Bosne 33-35, 71000 Sarajevo, Bosnia and Herzegovina; amra.banda@pmf.unsa.ba

* Corresponding author: Amra Banda; e-mail: amra-catovic@hotmail.com; amra.banda@pmf.unsa.ba, tel.+38733723803 
nia and Herzegovina (Hamad et al., 2010). Skiing, as a most common winter tourism activity became popular on Bjelašnica since 1950's. First skis were brought in village Šabići in 1957 and during the 1957 and 1958 ski courses on Bjelašnica were organized. Although through history, mountain area of Bosnia and Herzegovina were very popular for hiking, mountaineering and skiing (Šehić, 1985), they are still not sufficiently well-established tourism destinations.

The study area of this research is Bjelašnica, mountain tourist area of exceptional value, which is favourably exploited due to their location: in the central part of the state, $30 \mathrm{~km}$ far from the capital city of Sarajevo. Bjelašnica is karst mountain, which on average is covered with snow for several months, usually from November to May, and sometimes in the summer (Drešković et. al., 2015). Apart from ski resort, Bjelašnica is a popular weekend picnic area, attractive because of opportunities for hiking, mountain biking, and water sports (rafting and canoeing on the nearby rivers), paragliding, suitable for the development of summer alternative tourism supply (Gafić \& Džeko, 2011). It is an extremely important destination for the development of dominant winter mountain tourism, then rural tourism, as well as various sports and recreational activities in Bosnia and Herzegovina.

Bjelašnica is a representative example of mountain tourism destination that has passed through several stages of tourism development. These six stages (Table 1) do not correspond entirely to typical developmental stages of Butler's tourism area life cycle model, but each stage has a specific recreational and tourism activities, i.e. vary in share and significance of alternative tourism supply (Banda \& Opačić 2017).

In the last two decade, tourism on Bjelašnica has developed rapidly resulting with severe environmental consequences. Also, ski resorts such as Bjelašnica face the problems of global warming and winters poor in snow. Taking this into account, Bjelašnica started gradual development of alternative forms of tourism, which are also important for extending the tourist season. These alternative forms, such as rural and ecotourism preserve the environment and cultural heritage as well as respect the local community.

"New tourists" find especially attractive climbs to the highest peak Observatory, Hranisava, Obalj and Krvavac. As an important element of the geomorphological attractions is Megara cave, also known under the name of Kuvija, located in the western part of Bjelašnica (range Preslica, on the north slope of the hill Orlovac). Among the most important tourism attraction of Bjelašnica for the development of alternative tourism is certainly Rakitnica river canyon. Rakitnica canyon is morphological phenomenon developed in the zone of deep karst, which separates Bjelašnica from Visočica (Lepirica, 2005). It is popular among tourists especially from May to October. The most popular hydrographic landscape element of Bjelašnica mountain area is Studeni potok, which is known by its meanders, which are reminiscent of the legend of the dragon-large snake. Bjelašnica is a mountain that is characterized by great wealth and di-

Table 1. Stages of tourism development on Bjelašnica Mountain

\begin{tabular}{|c|c|}
\hline PERIOD & CHARACTERISTICS \\
\hline $\begin{array}{l}\text { 1878-1918 } \\
\text { (Austria-Hungary) }\end{array}$ & $\begin{array}{l}\text { - construction of hiking facilities } \\
\text { - publication of mountain guides } \\
\text { - first recreational-tourism trips }\end{array}$ \\
\hline $\begin{array}{l}\text { 1918-1945 } \\
\text { (between World War I and World War II) }\end{array}$ & $\begin{array}{l}\text { - large number of field trips } \\
\text { - first alpine feats } \\
\text { - ski competitions during the event "Bjelašnički dani" } \\
\text { - development of primarily winter recreational supply }\end{array}$ \\
\hline $\begin{array}{l}1945-1978 \\
\text { (after World War II until assigning Sarajevo to be } \\
\text { the host of 14th Winter Olympic Games) }\end{array}$ & $\begin{array}{l}\text { - } 1957 \text { first skis on Bjelašnica } \\
\text { - beginning of ski courses (1957 and 1958) } \\
\text { - development of winter and summer recreational supply } \\
\text { - significant number of travellers in mountain houses }\end{array}$ \\
\hline $\begin{array}{l}1978-1992 \\
\text { (Winter Olympic Games } 1984 \text { until breakup of } \\
\text { Yugoslavia) }\end{array}$ & $\begin{array}{l}\text { - predominance of mass winter ski tourism supply } \\
\text { - attempts to extend tourism season with lower hotel } \\
\text { prices in summer } \\
\text { - international ski competitions }\end{array}$ \\
\hline $\begin{array}{l}\text { 1996-2000 } \\
\text { (post-war tourism reconstruction) }\end{array}$ & $\begin{array}{l}\text { - reconstruction of facilities } \\
\text { - winter tourism supply still prevailing }\end{array}$ \\
\hline $\begin{array}{l}\text { after } 2000 \\
\text { (modern period) }\end{array}$ & $\begin{array}{l}\text { - } \text { winter tourism and recreational supply } \\
\text { - efforts in developing summer tourism supply } \\
\text { - problems with unplanned construction } \\
\text { - lack of tourism development strategy }\end{array}$ \\
\hline
\end{tabular}

Source: Banda, Opačić 2017 
versity of the plant world, particulary in the Rakitnica canyon. Mountain landscape of Bjelašnica is also recognizable for their villages. Lukomir, highest altitude and most remote village in the entire country is known by its vernacular architecture. Tourists visit it in summer in order to taste local food and see it specific architecture (Temimović \& Jahić, 2009). This whole region is marked with old cattle and caravan roads which date back to Roman times. Among the most numerous monuments of medieval period are "stećci" (medieval tombstones) from the 14th or 15th century near the village Tušila, between Bjelašnica and Visočica (Bešlagić, 2004).

In the recent period 2000-2017., Bjelašnica can be observed as a mountain destination with the winter tourism supply, which seeks to expand tourism season throughout the year.

In tourism market, Bjelašnica is still known as a winter ski tourism destination. Ski centre Bjelašnica includes downhill trail, which leads from the top of the mountain $(2067 \mathrm{~m})$ to Babin Do (1300 m). Almost parallel to it are three steeper slopes, which were used for training athletes. The trails for giant slalom and slalom are located on the east side of the mountain and trail Kolijevka is ideal for beginners. According to Activity plan for KJKP ZOI'84 for the location Bjelašnica (2011), vertical transport includes two-seat and three-seat cable cars, five ski lifts and a few baby lifts (capacity of 5,000 skiers per hour). Trail for night skiing is part of the downhill-run, in the finish area (total length $750 \mathrm{~m}$ ). Tourists can also rent ski equipment. As a part of alternative tourism supply, snowboarding and ski touring are developing. Accommodation facilities on Bjelašnica include hotels Maršal, Han and Bjelašnica, mountain houses and private facilities that offer apartments and rooms (Hamad et al., 2010). Alternative tourism supply in summer is very poor. Tourists, mostly foreign come in organized groups to visit villages (for example Lukomir and Umoljani), sightseeing locations and to have lunch. Among tourists, very popular is also quad bike ride. In future, strong development of tourism and recreational activities is planned in the area of Babin Do, the main point of winter recreation. The extension of this zone is planned to massif Šiljak with the target areas in Štinji Do and Donja Grkarica (Sustainable Development Strategy of Trnovo Municipality, 2013).

According to Banda and Opačić (2017), Bjelašnica is faced with numerous challenges and problems in alternative tourism supply development, such as:

- traffic congestion and insufficient parking place;

- sewage problem;

- obsolete vertical transportation;

- tourism attractions by the winter season is almost nonexistent;

- poorly developed alternative tourism supply for the winter months;

- the lack of facilities after skiing (for example wellness);

- insufficient utilization of tourism potential of other tourism attractions.

The objective of the study to identify the evaluation of tourism attractiveness of attractions of alternative tourism in tourism supply of Bjelašnica, as well as to determine the differences in the evaluation of tourism attractions: a) between local residents and tourists, b) between local residents considering the age, gender and level of education, c) between tourists considering the age, gender and level of education, and d) between tourists who stay at villages of Bjelašnica and tourists who stay at the purpose-built tourist resort Babin Do.

\section{Literature review}

Numerous authors in their research have analyzed physical-geographical and social-geographical characteristics as well as the historical development and cultural heritage of the mountainous area of Bosnia and Herzegovina. However, tourism and tourism-geographical research in mountain areas has not been paid great attention.

The scientific and economic interest for mountain tourism in Bosnia and Herzegovina, as well on Bjelašnica has been underlined in economic studies and spatial-planning documentation such as Study of the long-term development of tourism in Bosnia and Herzegovina by Bogdanović (1970) and Strategy of tourism development of SR BßH by Praljak-Kesić (1987). Extensive spatial planning documentation was prepared for the $14^{\text {th }}$ Winter Olympics, including Spatial plan of the special area for the maintenance of the $14^{\text {th }}$ Winter Olympics Sarajevo (for the mountain areas Igman, Bjelašnica and Jahorina).

Mihić (1984) published a book titled Bjelašnica and Igman - Mountains of $14^{\text {th }}$ Winter Olympic Games that presents detailed geographical features of Bjelašnica and Igman, as well as development of mountain tourism, mountaineering and skiing on Bjelašnica and Igman through history, with special chapter dedicated to the XIV Winter Olympics. Among the first geographers to write about Bjelašnica mountain tourism was also Čehajić (1987) in her doctoral thesis Tourism development in Bosnia and Herzegovina - geographical study. 
Many mountain guides with information for tourists about hiking trails and mountain huts on Bjelašnica and other mountains were also published, among which should be mentioned Mountaineering \& Tourist Guide on Mountains Around Sarajevo by Babić and Bozja (2006). In 2007, Master plan for development of rural eco-tourism in area of Bjelašnica was conducted, which presents analysis of tourism attraction base of alternative tourism.

Also significant is a paper titled Regional aspects of tourist potentials of Canton Sarajevo - classification and valorisation by Nurković et al. (2009) as it represents a scientific literature in the field of geography that analysis tourism potential of the mountainous area of Bjelašnica. In the same year, in the paper Development potentials of rural tourism on Bosnia and Herzegovina mountains with special review on village Lukomir, authors Temimović and Jahić discuss rural tourism in Bjelašnica's villages. Hamad et al (2010), give a different perspective analysing Bjelašnica and other mountains as ski resorts in their paper titled A Competitive Analysis Of Ski Resorts In Bosnia And Herzegovina Using Differential Advantage Proforma.

In scientific literature, tourist satisfaction has been identified as an important concept in establishing the performance of different destinations. According to Peter and Olson (1996), level of tourist satisfaction with a particular trip is the result of different factors, i.e. level of tourists satisfaction will depend both on their expectations regarding the attractions and attributes in the destination, and of course from the perception of the outcome. Danaher and Arweiler (1996) established that, positive tourist feedback is focused mainly on outdoor activities, although the experience associated with transport and accommodation affect the degree of tourist satisfaction. It is important for the mountain tourism destinations that supply vary of outdoor activities to understand that the activities performed during the stay at the holiday destination and the experiences during these activities are clear sources of satisfaction for the tourist.

Despite the amount of research focusing on studying the level of tourist satisfaction, there is a need to investigate the relationship between destination attractions and tourists' satisfaction from the tourist's perspective in order to gain an in-depth understanding of tourists' attitudes and behaviour after they visit certain mountain destinations.

Tourists and the local community differently perceive and evaluate tourism attractions. Researchers have tested a number of socio-demographic fac- tors (age, sex, education, income, length of residence, knowledge of tourism involvement in tourism activity) that may affect people's attitudes. In the literature, there are many studies surveying attitudes of residents towards tourism development (Perdue et al., 1991; Ap, 1992; Lankford \& Howard, 1994; Andereck \& Vogt, 200o; Mason \& Cheyne, 2000; Sheldon \& Abenoja, 2001; Gursoy et al., 2002; Easterling, 2004; Aguilo \& Rosselo, 2005; Andiotis, 2005; Ritchie \& Inkari, 2006; Huh \& Vogt, 2008; Ogorelc, 2009; Sharma \& Dyer, 2009; Frauman \& Banks 2011; Vargas et al., 2011;). On the other hand, only a few studies have explicitly considered perceptions of residents toward tourism attractions (McClung, 1991; Thach \& Axinn, 1994; Alhemoud \& Armstrong, 1996; Wong \& Cheung, 1999; Jurowski \& Gursoy 2004; Lawton, 2005).

Taken collectively, the many surveys of residents demonstrate that one cannot presume uniformity among local people in their views of tourism and its attractions. Researchers have shown that the members of the local community, who are employed in tourism industry or have personal economic benefits from tourism development, are generally more favourable towards tourism than those who are not (Haralambopoulos \& Pizam, 1996; Brunt \& Courtney, 1999; Sirakaya et al., 2002; McGehhe \& Andereck, 2004; Andereck et al. 2005; Vargas-Sanchez et al., 2009). Some authors disagree with these statements and conclude that residents being economically dependent on tourism find more negative association with tourism manifesting this in a strong negative attitude (Pizam et al., 1978; Williams \& Lawson, 2001; Teye et al., 2002). On the same argument, we can conclude that residents' perception of tourism is influenced by the possibility of having an economic gain (Haralambopoulos \& Pizam, 1996; Gilbert \& Clark, 1997; Brunt \& Courtney, 1999; Sirakaya et al., 2002; McGehee \& Andereck, 2004).

Alternative forms of tourism actually encourage the development of products based on the comparative advantages of each destination attractions. Provision of appropriate tourism infrastructure should come together with tourism attraction elements in order to develop alternative tourism supply. The mix of destination attractions and facilities create a set of intangible "subjective experiences" for tourists known as tourism product (Kim, 2001).

To know how destination and their attractions are perceived is especially important in order to attract visitors. Image perception is not solely a result of media tools since it develops out of a combination of several personal experiences (Horrigan, 2009). 


\section{Methodology}

The evaluation of tourism attractiveness of attractions of alternative tourism by local residents and tourists was made in direct questionnaire survey using the commemorative sample method in villages of Bjelašnica (Brda, Dejčići, Lukomir, Šabići, Umoljani) with registered tourism activity, as well as in a tourist resort Babin Do without local residents (Figure 1).
Research instrument consisted of socio-demographic variables (gender, age, education, employment, marital status, monthly income) and evaluation of tourism attractiveness of the attraction base elements of alternative tourism as well as tourism and recreational infrastructure. Research instrument for local residents included additionally question of their

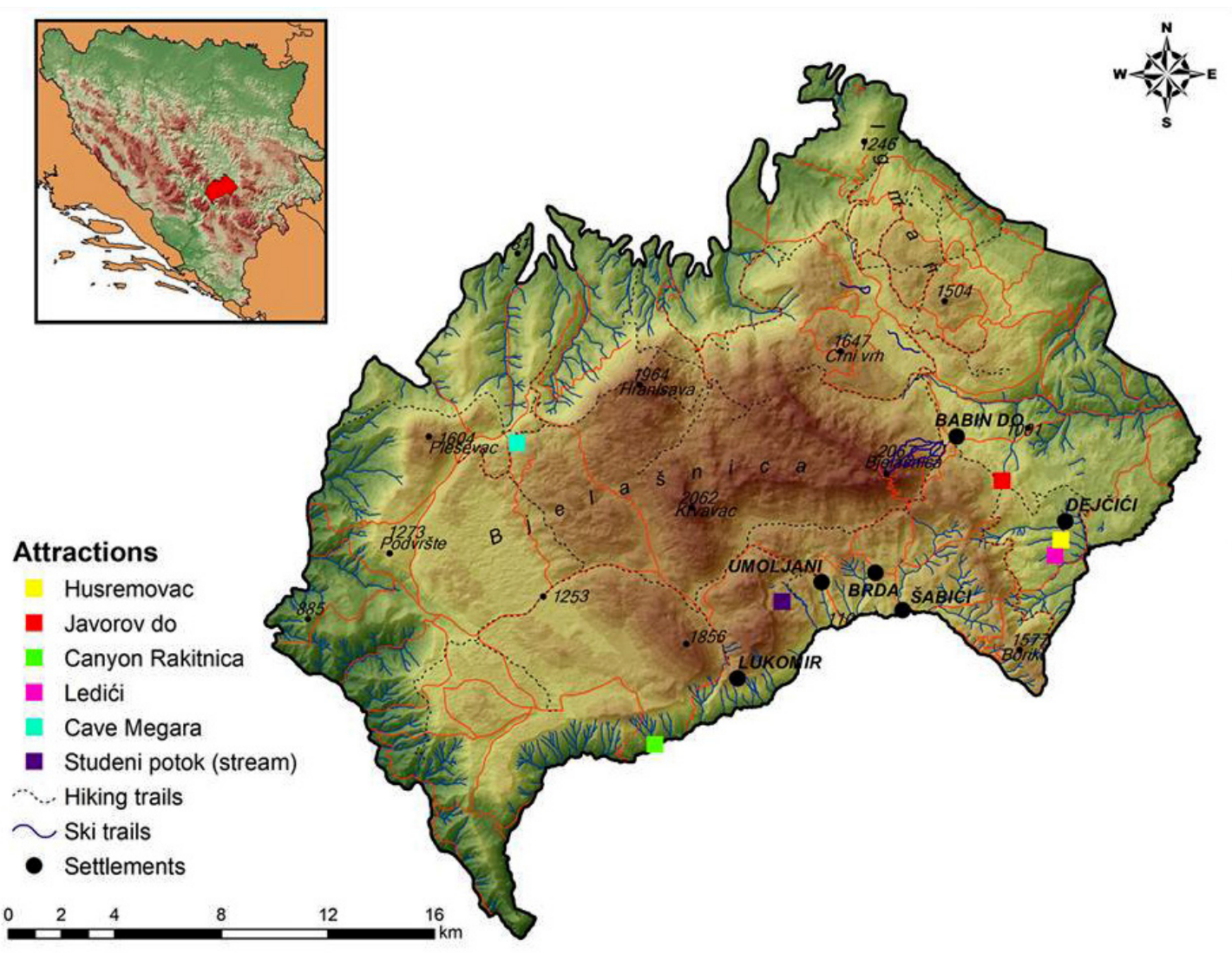

Figure 1. Tourism attractions of alternative tourism on Bjelašnica analysed in the survey

Source: according to the topographic map of Bosnia and Herzegovina, sheet Sarajevo, R 1: 200 000, edited by authors, 2017

The evaluation of tourism attractiveness of attractions of alternative tourism on Bjelašnica was made using the scale of 5 marks in which the grade 1 indicated the lowest tourism attractiveness and grade 5 the highest tourism attractiveness. The population in the survey conducted during the summer 2016 consisted of adult permanent residents in mentioned villages as well as tourists who had at least one overnight stay in these villages or in Babin Do. Questionnaires were filled face to face during the weekends in June and respondents were included based on their accessibility and willingness. Therefore convenient sample was used. Prior to fulfilling questionnaire respondents were informed about the survey and that anonymity would be guaranteed. Survey sample consisted of 98 local residents and 111 tourists. residential area, while research instrument for tourists included question about their place of stay in destination. For the better illustration and interpretation of the results, the individual tourism attractions of alternative tourism indicated in the survey ( 17 in total) were classified into 6 common tourism attractions, i.e. clusters modelled on Kušen's classification of tourism attractions (2002; 2010) (Table 2).

Besides descriptive statistics (average valuation and the frequency of respondents' answers), the survey carried out the statistical analysis in SPSS program to determine the differences in the evaluation of tourism attractiveness of the attraction base elements of alternative tourism, using standard statistical methods: correlation analysis, one-way ANOVA and t-test. 
Table 2. Classification of tourism attractions of alternative tourism on Bjelašnica used in the survey

\begin{tabular}{|c|c|}
\hline $\begin{array}{l}\text { COMMON TOURISM ATTRACTIONS } \\
\text { (CLUSTERS) }\end{array}$ & INDIVIDUAL TOURISM ATTRACTIONS \\
\hline \multirow{3}{*}{$\begin{array}{l}\text { Climate and geomorphological } \\
\text { characteristics }\end{array}$} & climate characteristics \\
\hline & canyon of river Rakitnica \\
\hline & cave Megara \\
\hline \multirow{4}{*}{ Landscape } & landscape characteristics \\
\hline & Javorov do \\
\hline & Studeni potok (stream) \\
\hline & Husremovac and Ledići villages \\
\hline \multirow{4}{*}{ Cultural and historical heritage } & "stećci" (medieval tombstones) \\
\hline & mosque in Umoljani village \\
\hline & watermills in Umoljani village \\
\hline & Lukomir village \\
\hline \multirow{2}{*}{ Culture of life and work } & traditional cattle breeding \\
\hline & local gastronomy \\
\hline \multirow{2}{*}{ Events } & "Days of mountain biking" \\
\hline & "Mountaineers encounters" \\
\hline \multirow{2}{*}{ Tourism and recreational infrastructure } & tourist resort Babin Do \\
\hline & hiking trails - Via Dinarica \\
\hline
\end{tabular}

Source: authors classification according to Kušen's theoretical model (2002;2010)

\section{Results and discussion}

\section{Sample characteristics}

It can be noticed that in the survey sample with both local residents and tourists dominate men (Table 3 ).

Survey population of local residents is much older comparing to tourists with difference of more than 20 years between average age of two groups of respondents. Also, tourists are more educated than local residents, which can be explained with negative demographic consequences of long term emigration of younger and more educated population from moun- tain area of Bosnia and Herzegovina, and also with the fact that tourists in mountain tourism destinations are more educated than local residents. In survey sample of tourists, more than three quarters stayed in Bjelašnica's villages, while less than one quarter stayed at tourist resort Babin Do. This stratification of participants was carried out because the main part of alternative tourism supply on Bjelašnica is concentrated outside of Babin Do, tourist resort mainly focused on mass ski tourism.

Table 3. Sociodemographic structure of respondents

\begin{tabular}{|l|l|c|c|}
\hline \multicolumn{2}{|l|}{ SAMPLE CHARACTERISTICS } & $\begin{array}{c}\text { LOCAL RESIDENTS } \\
(\mathrm{N}=98)\end{array}$ & $\begin{array}{c}\text { TOURISTS } \\
(\mathrm{N}=111)\end{array}$ \\
\hline \multirow{3}{*}{ Gender (\%) } & Men & 53.06 & 55.86 \\
\cline { 2 - 4 } & Women & 46.94 & 44.14 \\
\hline \multirow{3}{*}{ Average age (years) } & $\begin{array}{c}\text { M=57.18 } \\
(\mathrm{SD}=16.19)\end{array}$ & $\begin{array}{c}\text { M=34.46 } \\
(\mathrm{SD}=9.07)\end{array}$ \\
\hline \multirow{3}{*}{\begin{tabular}{l} 
Level of education (\%) \\
\cline { 2 - 4 }
\end{tabular}} & Primary school & 33.67 & - \\
\cline { 2 - 4 } & High school & 45.92 & 30.63 \\
\cline { 2 - 4 } & College & 16.32 & 19.81 \\
\cline { 2 - 4 } & University and higher (PhD) & 4.08 & 49.55 \\
\hline $\begin{array}{l}\text { Residence (for local residents)/ } \\
\text { Place of stay (for tourists) (\%) }\end{array}$ & Bjelašnica's villages & 100.00 & 75.68 \\
\cline { 2 - 4 } & Babin Do & - & 24.32 \\
\hline
\end{tabular}

Source: results of the questionnaire survey, June 2016 


\section{The differences in the evaluation of tourism attractiveness of common attractions of alternative tourism between local residents and tourists}

T-test determined statistically significant differences in the evaluation of tourism attractiveness of common attractions of alternative tourism between local residents and tourists for all clusters except for the "climate and geomorphological attractions" (Table 4). However this cluster has high evaluations both by local residents and tourists. both local residents and tourists give highest grades for "landscape" and lowest for "tourism and recreational infrastructure.

When we look at the level of individual attractions evaluation, similar differences can be found on a descriptive statistical analysis. Comparing the average grades of attractiveness of the individual attractions, it can be concluded that local residents (in relation to tourists) find more attractive 5 out of 17 estimated individual attractions: canyon of river Rakitnica (aver-

Table 4. The evaluation of tourism attractiveness of common attractions of alternative tourism on Bjelašnica by local residents and tourists

\begin{tabular}{|c|c|c|c|c|c|}
\hline \multirow{2}{*}{ COMMON ATTRACTION(CLUSTER) } & \multicolumn{2}{|c|}{ LOCAL RESIDENTS } & \multicolumn{2}{|c|}{ TOURISTS } & \multirow{2}{*}{ T-TEST } \\
\hline & $M$ & SD & $M$ & SD & \\
\hline $\begin{array}{l}\text { Climate and geomorphological } \\
\text { attractions }\end{array}$ & 4.60 & 0.36 & 4.54 & 0.42 & $\begin{array}{c}t=1.060 \\
d f=207 \\
p=0.290\end{array}$ \\
\hline Landscape & 4.21 & 0.29 & 4.59 & 0.32 & $\begin{array}{c}t=-9.096 \\
d f=207 \\
p=0.000\end{array}$ \\
\hline Cultural and historical heritage & 4.18 & 0.42 & 4.31 & 0.41 & $\begin{array}{c}t=-2.213 \\
d f=207 \\
p=0.028\end{array}$ \\
\hline Culture of life and work & 3.85 & 0.54 & 4.11 & 0.75 & $\begin{array}{c}t=-2.914 \\
d f=207 \\
p=0.004\end{array}$ \\
\hline Events & 3.79 & 0.54 & 4.10 & 0.67 & $\begin{array}{c}t=-2.728 \\
d f=117 \\
p=0.007\end{array}$ \\
\hline Tourism and recreational infrastructure & 2.84 & 0.63 & 3.73 & 0.71 & $\begin{array}{c}t=-9.518 \\
d f=117 \\
p=0.000\end{array}$ \\
\hline
\end{tabular}

Source: results of the questionnaire survey, June 2016

It can be noticed that both locals and tourists give relatively high grades to common tourism attractions of alternative tourism on Bjelašnica. In the evaluation of some individual attractions was not found any significant variability of answers (for example, all respondents graded tourism attractiveness of canyon of river Rakitnica with 4 and 5). The tourists found all clusters more attractive than locals, with the exception of the cluster "climate and geomorphological attraction" that locals find slightly more attractive than tourists, which we can conclude from negative $\mathrm{t}$-values. Based on t-values and significance test, the biggest differences in evaluation are found in clusters "landscape" and "tourism and recreational infrastructure". Significant differences are found in clusters "cultural and historical heritage", "culture of life and work" and "events", but $t$ and $p$ values suggest that these differences in evaluation are not so prominent as it is the case in previous two clusters. Among the clusters with statistically significant differences, age grade 4.93 by local residents and 4.82 by tourists), landscape characteristics (average grade 4.80 by local residents and 4.67 by tourists), mosque in Umoljani village (average grade 4.39 by local residents and 4.31 by tourists), watermills in Umoljani (average grade 4.23 by local residents and 3.96 by tourists) and local gastronomy (average grade 4.78 by local residents and 4.64 by tourists).

The tourists gave better grades because they are more thrilled with natural and cultural attractions, especially those who visited Bjelašnica for the first time ("wow factor"). For the numerous tourists, especially foreign tourists (Western and Central Europe, Middle East), the natural and cultural attractions of Bjelašnica represent the huge change in relation to physical environment and surroundings in, for instance, urban environment of the permanent residence, and that positively affects the grade. Similar was the research of Alhemoud and Armstrong (1996), where they state that more impressive to the tour- 
ists are attractions they do not see in their own country. Furthermore, we should keep in mind that tourists evaluate the attraction base elements in the period of vacations when they are more relaxed and tend to have more positive attitudes. Also, in that period they are motivated to get tourist experience in a chosen destination.

Perception of tourism attractions and positive tourism impacts is an important variable that influences residents' attitudes and opinions. Previous studies conducted by Perdue et al. (1991) and Brida et al. (2011) show that in the case of mountain destinations like Bjelašnica, tourism development is supported by the local community mainly if they have a positive perceptions regarding tourism attractions, environmental and economic impacts. Our research shows that local residents are not fully aware of the value and tourism attractiveness of natural and cultural possessions on Bjelašnica, mainly because they do not benefit from tourism as they should. Also, illegal construction of mainly accommodation facilities caused many environmental issues, which fully support the mentioned fact that locals are less willing to support tourism if they hold a negative perception of tourism impacts. According to Brida et al. (2011), residents perceiving tourism as a cause of increase of the investment at the destination and better public services will support tourism as well as its natural and cultural resources. On Bjelašnica, authorities do not invest enough in infrastructure (primarily traffic) or support local community in tourism development.

The common tourism attractions of "events" and "tourism and recreational infrastructure" as well as their individual attractions received the higher grades by tourists than by local residents. The differences in higher grades by tourists can be explained with the fact that attractions from mentioned clusters are designed specifically for tourists and recreationalists, so they are more familiar to tourists than for local residents. The local residents gave lower grades to tourist resort Babin Do in relation to tourists (average grade 2.33 by locals and 3.41 by tourists), so we can conclude that, although less educated, local residents are indeed aware of physiognomic and ecological unacceptability, oversize and unsuitability of this centre of mass winter tourism in a sensitive mountain ecosystem.

\section{The differences in the evaluation of tourism attractiveness of common attractions of alternative tourism between local residents considering the age, gender and level of education}

The differences in evaluation of tourism attractiveness of common attractions of alternative tourism in surveyed local population considering the age are examined using the correlation analysis. Negative correlation is found only between the age of participants and the evaluation of tourism attractiveness of the cluster "events" ( $\mathrm{r}=-0.376 ; \mathrm{p}=0.001)$ which indicates that as older the local residents are, they rate the events as less attractive. There are statistically significant differences in evaluation of the individual attractions of alternative tourism, for the event "Days of mountain biking" considering the age of local residents $(\mathrm{r}=$ -0.342; $\mathrm{p}=0.004$ ) whilst for another evaluated event "Mountaineers encounters" the difference is not found. It can be explained with the fact that mountain biking is less attractive activity for older respondents personal practicing as they have limited physical abilities, therefore they also find it less attractive in tourism supply.

The differences in evaluation of tourism attractiveness of common attractions of alternative tourism in surveyed local population considering the gender are examined using $\mathrm{t}$-test, but there are not found statistically significant differences for any of common tourism attractions.

Considering the level of education, the surveyed local population is classified into three categories: a) with primary school degree, b) with high school degree, and c) with college/university and higher degree $(\mathrm{PhD})$. Statistically significant difference in evaluation of tourism attractiveness of common attractions of alternative tourism considering the level of education of local residents is identified using the one-way ANOVA and it was only for the cluster "cultural and historical heritage" $(\mathrm{F}=3.266, \mathrm{df}=2, \mathrm{p}=0.042)$. The local population with high school degree finds it the most attractive for alternative tourism supply (average grade 4.28), followed by respondents with college/university degree (average grade 4.19) and in the end the respondents with primary school degree (average grade 4.04). As for the individual attractions in the domain of cultural and historical heritage, the statistically significant difference is found only for "stećci" (medieval tombstones) $(\mathrm{F}=3.172, \mathrm{df}=2, \mathrm{p}=0.046)$. Those tombstones became part of UNESCO World Heritage List (WHL) in 2016. WHL inscription contributes to positive and creative atmosphere in destination especially with the local entrepreneurs involved in tourism. Moreover, the presence of a World Heritage Sites generates positive expectations on local residents and tourists, as well as all stakeholders in tourism (Biagi 
\& Pulina, 2009). For mosque in Umoljani, watermills in Umoljani and Lukomir village, the differences between local residents considering the level of education are not identified.

\section{The differences in evaluation of tourism attractiveness of common attractions of alternative tourism between the tourists considering the age, gender and level of education}

The differences in the evaluation of tourism attractiveness of common attractions of alternative tourism in surveyed population of tourists considering the age are examined using the correlation analysis. Positive correlation is registered only between the age of respondents and the evaluation of tourism attractiveness of cultural and historical heritage $(\mathrm{r}=0.266 ; \mathrm{p}=0.005)$ which indicates that as older the tourists are, they find Bjelašnica's cultural and historical heritage as more attractive. In analyzing the evaluation of the individual attractions in domain of cultural and historical heritage, the statistically significant difference considering the age of tourists is noticed for "stećci" (medieval tombstones) ( $\mathrm{r}=0.232 ; \mathrm{p}=0.002)$, as well as for $\mathrm{Lu}$ komir village $(\mathrm{r}=0.191 ; \mathrm{p}=0.047)$ whilst for mosque and watermills in Umoljani village the difference is not found. Positive correlation between the age of surveyed tourists and individual attractions of alternative tourism is recorded for traditional cattle breeding from common tourism attraction "culture of life and work" $(\mathrm{r}=0.309 ; \mathrm{p}=0.015)$ as well as for canyon of river Rakitni$\mathrm{ca}(\mathrm{r}=0.236 ; \mathrm{p}=0.019)$ from common tourism attraction "climate and geomorphological attractions". The given result confirms the theory that cultural and natural heritage as tourism attractions are more attractive to older tourists. Looking at tourism attractions, culture and nature, were most important among senior tourists, when choosing holiday destination according to the European Commission project ESCAPE (European Senior Citizens' Actions to Promote Exchange in Tourism) Report on Senior Tourists Needs and Demands (2017). As in our case, cultural and historical heritage were preferred tourism attractions, among respondents in the mentioned project. Senior tourists gave highest preferences to clean nature and affordable cost of the natural and cultural heritage sites when choosing holiday destinations.

The differences in evaluation of tourism attractiveness of common attractions of alternative tourism between tourists considering the gender are examined using t-test, but statistically significant differences are not found for any of common tourism attractions.

Considering the level of education, the surveyed tourists are classified into three categories: a) with high school degree at least, b) with college degree, and c) with university degree or higher $(\mathrm{PhD})$. Statistically significant difference in evaluation of tourism attractiveness of common attractions of alternative tourism considering the level of education of tourists is determined using one-way ANOVA and it was only for "tourism and recreational infrastructure" $(\mathrm{F}=4.109$, $\mathrm{df}=2, \mathrm{p}=0.019$ ). The surveyed tourists with college degree find it the most attractive (average grade 4.11), followed by respondents with university degree (average grade 3.65), and in the end the surveyed tourists with high school degree and primary school degree (average grade 3.63). In determining the differences in the evaluation of the individual attractions from this cluster, the statistically significant difference between the tourists considering the level of education is found for purpose-built tourist resort Babin Do that is ponderous in the whole cluster "tourism and recreational infrastructure" $(\mathrm{F}=3.445, \mathrm{df}=2, \mathrm{p}=0.035)$. Tourist attractiveness of Babin Do is rated with the highest grades by participants with college degree (average grade 3.86), followed by surveyed tourists with university degree (average grade 3.31), and in the end the respondents with high school degree and primary school degree (average grade 3.26). Based on this it can be assumed that purpose-built tourist resorts with catering and entertainment supply are most interesting to average educated tourists that, generally, are not interested in cultural and historical heritage in less visited parts of Bjelašnica, but on the other hand, are financially able to visiting/staying in "popular" tourist resorts. They are not so much bothered with their physiognomic and ecological unsuitability in a sensitive mountain ecosystem. The most educated tourists are not "wowed" when visiting Bjelašnica, because a central element of their visit is often the learning dimension. Garms et al. (2016), conducted a research among German tourists in Scandinavian mountains, and came up with similar results. Visitors in this research wanted to learn more about plants, animals, or just the ecosystem as a whole. Brochures, information boards, and guided tours (which lack on Bjelašnica) were highly appreciated. It can be assumed that more educated tourists evaluate attractiveness of Babin Do with lower grades because they expected more information in destination. Also, clearly signposted hiking trail network and a visitor centre, guarantee a certain feeling of safety when being on the mountain. On the other hand, tourists with high school degree evaluate tourist attractiveness of Babin Do with lowest grades which can be explained with their lowest income certain activities in tourism supply over there are less available to them. 


\section{The differences in the evaluation of tourism} attractiveness of common attractions of alternative tourism between tourists who stay in Bjelašnica's villages and tourists who stay in tourist resort Babin Do

The statistically significant differences in the evaluation of tourism attractiveness of common attractions of alternative tourism between tourists who stay in Bjelašnica's villages (Brda, Dejčići, Lukomir, Šabići, Umoljani) with registered tourism activity and tourists who stay at tourist resort Babin Do are determined using t-test, for the following clusters: "climate and geomorphological attractions", "culture of life and work", and "tourism and recreational infrastructure" (Table 5). reational infrastructure". Significant differences are found in clusters "climate and geomorphological attractions" and "culture of life and work", but $t$ and $\mathrm{p}$ values suggest that these differences in evaluation are not so prominent as it is the case in the previous. Among the clusters with statistically significant differences, both tourists in Bjelašnica's villages and Babin Do give highest grades for "climate and geomorphological attractions" and lowest for "tourism and recreational infrastructure".

When we look at the level of individual attractions evaluation, similar differences can be found on a descriptive statistical analysis. Comparing the average grades of attractiveness of the individual attractions, it can be concluded that tourists who stayed at Babin

Table 5. The evaluation of tourism attractiveness of common attractions of alternative tourism on Bjelašnica by tourists who stayed in Bjelašnica's villages and tourists who stayed in tourist resort Babin Do

\begin{tabular}{|c|c|c|c|c|c|}
\hline \multirow[t]{2}{*}{ COMMON ATTRACTION } & \multicolumn{2}{|c|}{$\begin{array}{c}\text { TOURISTS IN } \\
\text { BJELAŠNICA'S } \\
\text { VILLAGES }\end{array}$} & \multicolumn{2}{|c|}{$\begin{array}{l}\text { TOURISTS } \\
\text { AT BABIN DO }\end{array}$} & \multirow[t]{2}{*}{ T-TEST } \\
\hline & M & SD & M & SD & \\
\hline $\begin{array}{l}\text { Climate and geomorphological } \\
\text { attractions }\end{array}$ & 4.48 & 0.42 & 4.73 & 0.40 & $\begin{array}{c}t=-2.697 \\
d f=109 \\
p=0.008\end{array}$ \\
\hline Landscape & 4.58 & 0.32 & 4.63 & 0.33 & $\begin{array}{c}t=-0.735 \\
d f=109 \\
p=0.464\end{array}$ \\
\hline Cultural and historical heritage & 4.29 & 0.40 & 4.35 & 0.47 & $\begin{array}{c}t=-0.657 \\
d f=207 \\
p=0.512\end{array}$ \\
\hline Culture of life and work & 4.02 & 0.78 & 4.39 & 0.54 & $\begin{array}{c}t=-2.250 \\
d f=109 \\
p=0.026\end{array}$ \\
\hline Tourism and recreational infrastructure & 3.63 & 0.64 & 4.07 & 0.82 & $\begin{array}{c}t=-2.945 \\
d f=109 \\
p=0.004\end{array}$ \\
\hline
\end{tabular}

Source: results of the questionnaire survey, June 2016

It can be seen that tourists at Babin Do find all clusters more attractive than tourists in villages of Bjelašnica, which we can conclude from negative t-values. Based on t-values and significance test, the biggest differences in evaluation are found in cluster "tourism and rec-

\footnotetext{
Most of tourists who stay in tourist resort Babin Do are not familiar with the two events from the survey ("Days of mountain biking" and "Mountaineers encounters") and for that reason it wasn't possible to examine if there are statistically significant differences between tourists who stayed in Bjelašnica's villages and tourists who stayed in Babin Do when evaluating the cluster "events" nor when evaluating the individual attractions "Days of mountain biking" and "Mountaineers encounters". This confirms the theory that tourists who stay at tourist destinations of mass tourism are less introduced with alternative tourism supply. Moreover, they are less interested in life of local community in destination.
}

Do in relation to tourists in Bjelašnica's villages find more attractive 9 out of 15 examined individual attractions: climate characteristics (average grade 4.63 given by tourists from Babin Do and 4.43 by tourists from Bjelašnica's villages), canyon of river Rakitnica (average grade 4.94 by tourists from Babin Do and 4.79 by tourists from Bjelašnica's villages), cave Megara (average grade 4.00 by tourists from Babin Do and 3.42 by tourists from Bjelašnica's villages), landscape characteristics (average grade 4.81 by tourists from Babin Do and 4.62 by tourists from Bjelašnica's villages), mosque in Umoljani village (average grade 4.52 by tourists from Babin Do and 4.25 by tourists from Bjelašnica's villages), Lukomir village (average grade 4.88 by tourists from Babin Do and 4.57 by tourists from Bjelašnica's villages), traditional cattle breeding 
(average grade 3.60 by tourists from Babin Do and 3.12 by tourists from Bjelašnica's villages), Babin Do (average grade 4.04 by tourists who stayed there and 4.79 by tourists from Bjelašnica's villages) and hiking trails Via Dinarica (average grade 4.40 by tourists from Babin Do and 4.20 by tourists from Bjelašnica's villages). This fact must be taken into account because, according to Yuksel and Yuksel (2001), lower grades may prompt tourists not to return in the future and may also impact on likelihood of recommending.

Regardless of lower grades by tourists from Bjelašnica's villages, it should be mentioned that areas as mountains are primarily appreciated in more urbanized countries for providing a contrast to the stress of urban life. Exploration of the typical landscape type is often as an incentive for visit (Garms et al. 2016), as also concluded from our survey, where landscape characteristics are highly graded by both tourists from Bjelašnica's villages and Babin Do. Though, tourists from the villages are more willing to learn about the tourism destination supply, while tourists from Babin Do are in a more stationary state. Resort visitor satisfaction levels are linked with the resort product's variety and tourism attractions i.e. what the resort has to offer in terms of facilities and utilities (Inbakaran et al., 2012). Therefore, tourists who stay in Babin Do are not very familiar with the wider area, so it is possible that they give grades without previous destination background knowledge, while tourists from Bjelašnica's villages are more interested for alternative tourism supply, and grade tourism attractions on their experience.
Based on the research of Li et al. (2008) and Donohoe (2012), tourists visit heritage sites to experience unique cultures, and to learn about destination's cultural identity, which confirms the fact that "stećci" (medieval tombstones) received high grades by tourists from Bjelašnica's villages as well as tourists from Babin Do (average grade 4.31 by tourists from Bjelašnica's villages and 4.16 by tourists from Babin Do). "Stećci" are being promoted as an important part of local history and tradition, especially since they have been listed in the UNESCO World Heritage List $^{2}$. On Bjelašnica, they have been embedded in history and cultural traditions of the local community. Watermills in Umoljani village (average grade 4.04 by tourists from Bjelašnica's villages and 3.67 by tourists from Babin Do), Husremovac and Ledići villages (average grade 4.22 by tourists from Bjelašnica's villages and 3.67 by tourists from Babin Do) received higher grades by tourists from Bjelašnica's villages. Here, we should emphasize that the mentioned villages received the higher grades by tourists who stayed there than the tourists from Babin Do - because for their attractiveness they have been chosen by those tourists at the first place. For the same reason, tourists who prefer staying at purpose-built tourist resorts and who stayed at Babin Do give higher grades to that resort than the tourists from the villages.

\footnotetext{
2 "Stećci" from Bosnia and Herzegovina, Serbia, Croatia and Montenegro were listed in the UNESCO World Heritage List in July, 2016.
}

\section{Conclusion}

The Olympic mountain Bjelašnica in Bosnia and Herzegovina is a typical example of mountain tourism destination where tourism supply was influenced by alternative forms of tourism in all of six developmental stages of tourism this mountain went through. Its tourism development has passed different political circumstances, with current challenge to reach successful recovery after the collapse of socialist Yugoslavia. In recent years, obvious are efforts in development of summer and winter alternative tourism supply as a supplement to mass ski tourism which is still the main tourism product of Bjelašnica.

For better development of alternative tourism supply it is necessary to identify and evaluate tourism attractions that could be better valorised when creating tourism products. It is an essential part of the destination analysis to determine perception of local residents and tourists when evaluating tourism attractiveness.
Based on the results of statistical analysis of the alternative tourism attraction base it can be concluded that both, local residents and tourists, evaluate common tourism attractions (clusters) of alternative tourism on Bjelašnica with relatively high grades, particularly "climate and geomorphological attractions", "landscape" and "cultural and historical heritage". Both groups give lowest grades for "tourism and recreational infrastructure". Tourists find all clusters more attractive than locals, except for the cluster "climate and geomorphological attractions" where there are no significant differences.

Regarding evaluations of local residents, there are no differences between male and female respondents. The statistical analysis determined only few differences in tourism attractiveness evaluation of common attractions of alternative tourism between local residents considering the age and level of education. As older local residents are, the less attractive they find 
the events that require physical forms of recreation (e.g. mountain biking) for they are limited in physical conditions. The local residents with high school degree find cultural and historical heritage the most attractive in alternative tourism supply, followed by participants with university degree, and in the end the participants with primary school degree.

Regarding tourists' evaluations, there are no differences between male and female respondents. The statistical analysis identified some differences in tourism attractiveness evaluation with regard to age and education. Older tourists find the "cultural and historical heritage" of Bjelašnica more attractive. Statistically significant difference in the evaluation of tourism attractiveness of alternative tourism clusters considering the level of education of tourists is found only for the cluster "tourism and recreational infrastructure". It is the most attractive to tourists with college degree before the ones with university degree and high school/primary school degree.

The results of statistical analysis show that all cluster attractions of alternative tourism are rated as more attractive by mass-tourists who stay at Babin Do, as a form of purpose-built mountain tourist resort, than individual tourists from Bjelašnica's villages.

To sum up, Bjelašnica as a typical mountain destination is now in mature development stage in its tour- ism development and that requires conceiving more complex tourism supply with integrated tourism products, not only of winter, but also of summer tourism, to attract more educated, broad-minded and wealthy tourists. Therefore, the stronger development of alternative forms of tourism that will valorise wide range of tourism attractions in destination can be expected soon. The future role of alternative forms of tourism in total tourism supply can serve in two periods: during winter time - as a supplement to prevailing tourism product of ski tourism, and during summer time - as the central part of Bjelašnica's tourism supply. The main zone of mass ski tourism is recognizable (tourist resort Babin Do), as well as the main zone of individual summer and alternative winter tourism (villages of Bjelašnica).

In order to reach this scenario it is necessary to create and implement the spatial planning documents in a short time, with clear guidelines of tourism development of Bjelašnica. It is also necessary to raise local residents' awareness of real and potential tourism attractions in their surroundings. It all should be done according the postulate of sustainable development in order not to jeopardize the present rich attraction base of alternative forms of tourism by excessive and inappropriate construction of tourism infrastructure.

\section{References}

Activity plan for KJKP ZOI'84 for the location Bjelašnica. (2011). Sarajevo: Center for economic, technological and environmental development (CETEOR). (in Bosnian) Available at: http://www. fmoit.gov.ba/userfiles/file/Plan\%2oaktivnosti\%20 ZOI\%2oBjela\%C5\%A1nica.pdf (30.11.2017.).

Aguilo, E., \& Rossello, J. (2005). Host Community Perceptions. A Cluster Analysis. Annals of Tourism Research, 4(32), 925-941.

Alhemoud, A.M., \& Armstrong, E.G. (1996). Image of Tourism Attractions in Kuwait. Journal of travel Research, 34(4), 76-80.

Andereck, K.L., \& Vogt, C.A. (2000). The Relationship between Residents' Attitudes toward Tourism and Tourism Development Options. Journal of Travel Research, 39(1), 27-36.

Andereck, K.L., Valentine, K.M., Knopf, R.C., \& Vogt, C.A. (2005). Residents' perceptions of community tourism impacts. Annals of Tourism Research, 32(4), 1056-1076.

Andiotis, K. (2005). Community groups' perceptions and preferences to tourism development. Evidence from Crete. Journal of Hospitality and Tourism Research, 29(1), 67-90.
Ap, J. (1992). Residents Perceptions on Tourism Impacts. Annals of Tourism Research, 19(4), 665-690.

Babić, B., \& Bozja, D. (2006). Mountaineering and Tourist Guide on Mountain Around Sarajevo. Sarajevo: Fondation "Pro-Bitra". (in Bosnian).

Banda, A., \& Opačić, V.T. (2017). Spatial Development of Tourism at the Olympic Mountains Bjelašnica and Igman. In N. Drešković (Ed.), Book of proceedings - 4th Congress of Geographers of Bosnia and Herzegovina. (pp. 810-826). Sarajevo: Geographical society of Federation of Bosnia and Herzegovina. (in Bosnian).

Bešlagić, Š. (2004). Lexicon of stećci (medieval tombstones). Sarajevo: Svjetlost. (in Bosnian).

Biagi, B., \& Pulina, M. (2009). Bivariate VAR models to test Granger causality between tourist demand and supply: Implications for regional sustainable growth. Papers in Regional Science, 88(1), 231-244.

Bogdanović, Đ. (1970). Study of the long-term development of tourism in Bosnia and Herzegovina. Sarajevo: Urbanist Institute of the Socialist Republic of Bosnia and Herzegovina. (in Bosnian).

Brida, J.G., Disegna, M., \& Osti, L. (2011). Residents' Perceptions of Tourism Impacts and Attitudes 
Towards Tourism Policies in a Small Mountain Community. SSRN Electronic Journal, doi:10.2139/ ssrn. 1839244

Brunt, P., \& Courtney, P. (1999). Host Perceptions of Sociocultural Impacts. Annals of Tourism Research, 26(2), 493-515.

Čehajić, J. 1987. Tourism development in Bosnia and Herzegovina - geographical study doctoral thesis. Sarajevo: University of Sarajevo, Faculty of Science. (in Bosnian)

Danaher, P.J., \& Arweiler, N. (1996). Customer Satisfaction in the Tourist Industry: A Case Study of Visitors to New Zealand. Journal of Travel Research, 35(1), 89-93.

Donohoe, H.M. (2012). Sustainable heritage tourism marketing and Canada's Rideau Canal world heritage site. Journal of Sustainable Tourism, 20(1), 121142.

Drešković, N., Pobrić, A., \& Đug, A. (2015). Tourism and potentials - mountain areas Bjelašnica, Treskavica, Visočica. Sarajevo: University of Sarajevo, Faculty of Science. (in Bosnian).

Easterling, D. (2004). The residents' perspective in tourism research: a review and synthesis. Journal of TravelङTourism Marketing, 17(4), 45-62.

ESCAPE (European Senior Citizens' Actions to Promote Exchange in Tourism): Report on Senior Tourists Needs and Demands. Available at: http://www. age platform.eu/images/ESCAPE_Needs_and_expectations_FINAL.pdf (08.04.2017.).

Frauman, E., \& Banks, S. (2011). Gateway community resident perceptions of tourism development: Incorporating importance-performance analysis into the limits of change framework. Tourism Management, 13(1), 128-140.

Gafić, M., \& Džeko, Š. (2011). Olympic Mountains of Sarajevo. Sarajevo: Tourist Board of Sarajevo Canton. (in Bosnian).

Garms, M., Fredman, P., \& Mose, I. (2016). Travel motives of German tourists in the Scandinavian mountains: the case of Fulufjället National Park. Scandinavian Journal of Hospitality and Tourism, 17(3), 239-258. doi:10.1080/15022250.2016.1176598

Gilbert, D., \& Clark, M. (1997). An Exploratory Examination of Urban Tourism Impact, with Reference to Residents Attitudes in the Cities of Canterbury and Guildford. Cities, 14(6), 343-352.

Gursoy, D., Jurowski, C., \& Uysal, M. (2002). Residents attitudes: a structural modelling approach. Annals of Tourism Research, 29(1), 79-105.

Hamad, M., Smajić, E., Mujkić, A., Bečić, A., Šabotić, A., Yurt, C., \& Duman, T. (2010). A Competitive Analysis Of Ski Resorts In Bosnia And Herzegovina Using Differential Advantage Proforma. In M. Handžić (Ed.), Proceedings of 2nd International
Symposium on Sustainable Development. (pp. 422428). International Burch University.

Haralambopoulos, N., \& Pizan, A. (1996). Perceived Impacts of Tourism: The Case of Samos. Annals of Tourism Research, 23(3), 503-526.

Heberlein, A.T., Fredman, P., \& Vuorio, T. (2002). Current Tourism Patterns in the Swedish Mountain Region. Mountain Research and Development, 22(2), 142-149.

Horrigan, D. (2009). Branded Content: A New Model For Driving Tourism Via Film And Branding Strategies. Tourismos, An International Multidisciplinary Journal of Tourism, 4(3), 51-65.

Huh, C., \& Vogt, C.A. (2008). Changes in residents' attitudes toward tourism over time: a cohort analytical approach. Journal of Travel Research, 46(4), 446455 .

Inbakaran, R., George, B., Jackson, M., Rodriques, E., \& Melo, F. (2012). Identifying resort tourism market segments based on visitor demographics: a study. Academica Turistica, 5(2), 85-94.

Jurowski, C., \& Gursoy, D. (2004). Distance effects on residents' attitudes toward tourism. Annals of Tourism Research, 31(2), 296-312.

Kim, C.S. (2001). Tourism Product Development: A Case Study of Wildlife Viewing in the Squamish Valley. Simon Fraser University. (Master Dissertation).

Kušen, E. (2002). Tourism attraction base. Zagreb: Institute for Tourism. (in Croatian).

Kušen, E. (2010). A system of tourism attractions. Tourism, 58(4), 409-424.

Lankford, S.V., \& Howard, D.R. (1994). Developing a Tourism Attitude Impact Scale. Annals of Tourism Research, 24(1), 121-139.

Lawton, L. (2005). Resident Perceptions of Tourist Attractions on the Gold Coast of Australia. Journal of Travel Research, 44(2), 188-200.

Lepirica, A. (2005). Basic morphological and morphostructural characteristics of the Rakitnica Canyon. Acta Carsologica, 34(2), 449-458.

Li, M., Wu, B., \& Cai, L. (2008). Tourism development of World Heritage Sites in China: A geographic perspective. Tourism Management, 29(2), 308-319.

Mason, P., \& Cheyne, C. (200o). Residents' attitude to proposed tourism development. Annals of Tourism Research, 27(2), 391-411.

Master plan for development of rural eco-tourism in area of Bjelašnica. (2007). Sarajevo: The Sarajevo Economic Region Development Agency (SERDA). (in Bosnian).

McClung, G.W. (1991). Theme Park Selection: Factors Influencing Attendance. Tourism Management, 12(2), 133-140. 
McGehee, N., \& Andereck, K. (2004). Factors Predicting Rural Residents' Support of Tourism. Journal of Travel Research, 43(2), 131-140.

Mihić, L. (1984). Bjelašnica and Igman - Mountains of 14th Winter Olympic Games. Sarajevo: SOUR "Veselin Masleša”. (in Bosnian).

Nurković, S., Mirić, R., Drešković, N., \& Jahić, H. (2009). Regional aspects of tourist potentials of Canton Sarajevo - classification and valorisation. In R. Nurković (Ed.), Proceedings of the International Scientific Seminar "Tourism as a Regional Developmental Factor”. (pp. 31-43). Tuzla: University of Tuzla. (in Bosnian).

Ogorelc, A. (2009). Residents' perceptions of tourism impacts and sustainable tourism development. International Journal of Sustainable Economy, 1(4), 373-387.

Perdue, R., Long, P., \& Gustke, L. (1991). The Effects of Tourism Development on Objective Indicators of Local Quality of Life. In Travel and Tourism Association 22nd Annual Proceedings. (pp. 191-201).

Peter, P.J., \& Olson, J.C. (1996). Consumer Behavior \& Marketing Strategy (4th ed). New York: McGrawHill.

Pizam, A., Neumann, Y., \& Reichel, A. (1978). Dimensions of tourism satisfaction with a destination area. Annals of Tourism Research, 5(3), 314-322.

Praljak-Kesić, T. (1987). Strategy of tourism development of SR B\&H. Economic Gazette, 37(4), 341-351. (in Bosnian).

Ritchie, B.W., \& Inkari, M. (2006). Host Community Attitudes Toward Tourism and Cultural Tourism Development: The Case of the Lewes District, Southern England. International Journal of Tourism Research, 8(1), 27-44.

Sharma, B., \& Dyer, P. (2009). An Investigation of Differences in Residents' Perceptions on the Sunshine Coast: Tourism Impacts and Demographic Variables. Tourism Geographies, 11(2), 187-213.

Sheldon, P.J., \& Abenoja, T. (2001). Resident attitudes in a mature destination: the case of Waikiki. Tourism Management, 22(5), 435-443.

Sirakaya, E., Teye, V., \& Sõnmez, S. (2002). Understanding Residents' Support for Tourism Development in the Central Region of Ghana. Journal of Travel Research, 41(1), 57-67.

Spatial plan of the special area for the maintenance of the 14th Winter Olympics Sarajevo. (1979). Sarajevo: Department for Urban Development Planning Sarajevo. (in Bosnian).
Sustainable Development Strategy of Trnovo Municipality. (2013). Sarajevo: Municipality of Trnovo. Available at: http://www.trnovo.ba/strategija-2012-2016/ (02.12.2017.); (in Bosnian).

Šehić, M. (1985). Transversal guide to the mountains of B\&H. Sarajevo: Mountaineering Union of Bosnia and Herzegovina. (in Bosnian).

Temimović, E., \& Jahić, H. (2009). Development potentials of rural tourism on Bosnia and Herzegovina mountains with special review on village Lukomir. In S. Musa (Ed.), Proceedings of the First international scientific symposium Transformation of the rural area of SE Europe in the conditions of transition and integration into the European Union. (pp. 217-225). Mostar: Geographical society of Herzegovina. (in Bosnian).

Teye, V., Sirakaya, E., \& Sönmez, S. (2002). Resident's Attitudes toward Tourism Development. Annals of Tourism Research, 29(3), 668-688.

Thach, P., \& Axinn, C.N. (1994). Patron Assessments of Amusement Park Attributes. Journal of Travel Research, 32(3), 51-60.

Vargas-Sánchez, A., de los Ángeles, P.M., \& PorrasBueno, N. (2009). Understanding residents' attitudes toward the development of industrial tourism in a former mining. Journal of Travel Research, 47(3), 373-387.

Vargas-Sánchez, A., Porras-Bueno, N., \& de los Ángeles, P.M. (2011). Explaining residents' attitudes to tourism. Is a universal model possible?. Annals of Tourism Research, 38(2), 460-480.

Voiculescu, M., Popescu, F., \& Olaru, M. (2012). Patterns of Winter Tourism Activity in the Bucegi Mountains - the Prahova Valley (the Southern Carpathians). Forum geographic Studii și cercetări de geografie și protecția mediului, 11(2), 182-194.

Williams, J., \& Lawson, R. (2001). Community issues and the resident opinions of tourism. Annals of Tourism Research, 28(2), 269-290.

Wong, K.F., \& Cheung, W.Y. (1999). Strategic Theming in Theme Park Marketing. Journal of Vacation Marketing, 5(4), 319-332.

Yang, M., Hens, L., Ou, X., \& de Wulf, R. (2009). Tourism: An Alternative to Development? Reconsidering Farming Tourism and Conservation Incentives in Northwest Yunnan Mountain Communities. Mountain Research and Development, 29(1), 75-81.

Yuksel, A., \& Yuksel, F. (2001). Comparative performance analysis: Tourists' perceptions of Turkey relative to other tourist destinations. Journal of Vacation Marketing, 7(4), 333-355. 